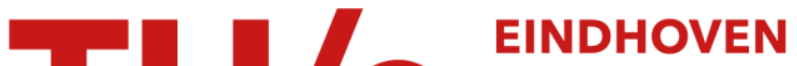 UNIVERSITY OF TECHNOLOGY
}

\section{Realizing sustainability of low cost apartments in Surabaya Indonesia by improving the adaptability}

\section{Citation for published version (APA):}

Kisnarini, R., Post, J. M., Egmond - de Wilde De Ligny, van, E. L. C., \& Mohammadi, M. (2013). Realizing sustainability of low cost apartments in Surabaya Indonesia by improving the adaptability. In First Annual International Conference on Architecture and Civil Engineering (ACE 2013), 18-19 March 2013, Singapore (pp. 318-323). (Architecture and Civil Engineering; Vol. 1). Global Science and Technology Forum (GSTF). https://doi.org/10.5176/2301-394X_ACE13.81

DOI:

10.5176/2301-394X_ACE13.81

Document status and date:

Published: 01/01/2013

\section{Document Version:}

Publisher's PDF, also known as Version of Record (includes final page, issue and volume numbers)

\section{Please check the document version of this publication:}

- A submitted manuscript is the version of the article upon submission and before peer-review. There can be important differences between the submitted version and the official published version of record. People interested in the research are advised to contact the author for the final version of the publication, or visit the $\mathrm{DOI}$ to the publisher's website.

- The final author version and the galley proof are versions of the publication after peer review.

- The final published version features the final layout of the paper including the volume, issue and page numbers.

Link to publication

\section{General rights}

Copyright and moral rights for the publications made accessible in the public portal are retained by the authors and/or other copyright owners and it is a condition of accessing publications that users recognise and abide by the legal requirements associated with these rights.

- Users may download and print one copy of any publication from the public portal for the purpose of private study or research.

- You may not further distribute the material or use it for any profit-making activity or commercial gain

- You may freely distribute the URL identifying the publication in the public portal.

If the publication is distributed under the terms of Article $25 \mathrm{fa}$ of the Dutch Copyright Act, indicated by the "Taverne" license above, please follow below link for the End User Agreement:

www.tue.nl/taverne

Take down policy

If you believe that this document breaches copyright please contact us at:

openaccess@tue.nl

providing details and we will investigate your claim. 


\title{
Realizing Sustainability of Low Cost Apartments in Surabaya Indonesia by Improving the Adaptability
}

\author{
Kisnarini R; Post JM; Egmond de Wilde de Ligny Ev; Mohammadi M. \\ Department of the Built Environment AUDE Technological University of Eindhoven (TU/e) \\ Eindhoven, the Netherlands \\ r.kisnarini@tue.nl
}

\begin{abstract}
Sustainability has been an absolute condition since the recent decades. To achieve sustainable building, one often struggle to reuse natural resources, minimize artificial energy, optimize natural energy, or else likewise. These efforts are in order to increase the building lifespan, as therefore construction waste can be eliminated. This paper is a part of $\mathrm{PhD}$ research work entitled:"Functionality and Adaptability of Low Cost Apartment Space Design in Tropical Developing Countries". Due to sustainability, enhancement of building lifespan in this research is realized not only by maintaining the functionality, but also by improving the adaptability, both of which are achieved from the users' side. Yet, adaptability is also anticipatable from building side by providing appropriate adaptable structure system and adequate space dimension.
\end{abstract}

This paper examines the adaptability of low cost apartments in Surabaya Indonesia. All 14 building types of public low cost rental apartment locations that developed by the government were taken as samples in this research. As total of apartment units in Surabaya is 3000-3500, 300 resident families were involved as respondents. Data of the buildings were collected by field survey and observation, copying the drawings, and interviewing the expert persons of housing department in charge. Assessment of adaptability is concentrated on unit level that consists of judgment of vertical adaptability which assesses the possibility of mezzanine construction, and horizontal adaptability which evaluates the possibility to occupy the corridor to the front, and to extend the balcony to the backward.

Finding regarding adaptability indicates that out of 300 only 16 households or $5 \%$ respondents installed mezzanine, 23 families or 8\% of them extended the balcony, and 97 residents or $32 \%$ respondents occupies the corridor. The results assume that Penjaringan-2, Wonorejo and Randu are the most adaptable apartments, while ITS is the most inadaptable.

Keywords-component; Adaptability; Sustainability; Low Cost Apartment Buildings in Surabaya.

\section{INTRODUCTION}

Nowadays every development concerns with sustainability. Builders, constructors, designers, developers should produce sustainable products, by which lifetime of earth is prolonged, and inhabitants are saved easier. The main research of this paper deals with functionality and adaptability, both of which concerned with building function that crucial for sustainability of the building. Functionality on one hand is responsible for the building function from the user side, while adaptability on the other hand takes care of the building function from the building side. Thus, the main research supports sustainability both from the user and building sides. When functionality deeply depends on users' household activities, that makes the project an activity based research, that is why users' characteristics is crucially important in determining the space demand; adaptability relies on not only the users, but also the physical capability of the building such as the building or unit dimension, construction, and structure system.

The research that deals with low cost apartments drew author's attention as land in Surabaya has been scarcer and more and more expensive. It is essential that urban housing especially those for low income families be moved from ground or horizontal housing system to vertical housing system although in reality these low cost apartments were developed outskirts of the city. Dense kampongs or villages were gradually changed by the government to become vertical housing complexes. To attract the poor willing to live in these dwelling spaces, more intensions of government regarding feasibility of living in low cost apartments are definitely needed. These apartment buildings are expected to serve its inhabitants not only for 5 years, but at least 10-15 year long. That is why maintaining the building function due to changing users' space demands is crucially required.

\section{METHODS}

300 families were recruited as respondents to see how they adapt their spatial demands to the available space. This amount was determined as the total units of low cost apartments in Surabaya are 3000-3500. The data were collected towards 14 building complex locations, therefore 21-22 respondents each became the user sample in the field research by questionnaires and in-depth interview.

In principle adaptability refers to the capacity of buildings to accommodate substantial changes (Jia 1993, Geraedts 2001, Moffat and Russel, 2001). Brand (1994) said "Almost no buildings adapt well, they're designed not to adapt, they have lives in time, and those lives are intimately connected with the lives of the people who use them. They change and perhaps grow as the lives of their users change. Eventually when for whatever reason, people no longer find them useful - they die. Architecture has trapped itself by insisting it is the art of building". It assumed that buildings should be able to change when the demand is changed. It is all because of lifespan. But when the buildings are separated into layers, not consists of 
only one entity, it is easier to manage and arrange the changes, since not the whole of the building required to be changed. (Moffat and Russel, 2001) It is especially important to uncouple those layers of a building that have significantly different lifetimes. The more often the function changed, the shorter the lifespan of the layer. Each layer of building has its own lifespan, such as that developed by Duffy (1992).

\begin{tabular}{|lll|}
\hline Layers & Elements & life time \\
1. Shell & Structure of building, including skin if load-bearing & $>50$ years \\
2. Services & Pipes, ducts, cables, machinery, elevators, escalators & $\sim 15$ years \\
3. Scenery & Partitioning, ceiling, finishes & $\sim 6$ years \\
4. Set & Furnishings, furniture, computers & monthly \\
\hline
\end{tabular}

A building has its own design lifespan that predicted by designer. The design lifespan may differ from the service lifespan, the reality happened to the building which depends on the building capability to adapt. Both Habraken (1966) and Brand (1994) basically have a similar premise: separating a building into layers. In principle, the most important thing should be emphasized, is separating such layers within a building that have significantly different lifetime. In low cost apartment building, the lifetime of the main structure and the lifetime of each unit interior are definitely different particularly due to the users or occupants' changing needs either in the same or different household. The main structure of the apartment building can reach $>50$ years, while the partitioning may be only 10-15 years even the duration of furniture use is no longer than 6 years (Moffat and Russel, 2001). Different from Duffi that differed a building into 4 layers, (Brand, 1994) differed it into 6, the fifth and sixth layers are the space plan and stuff.

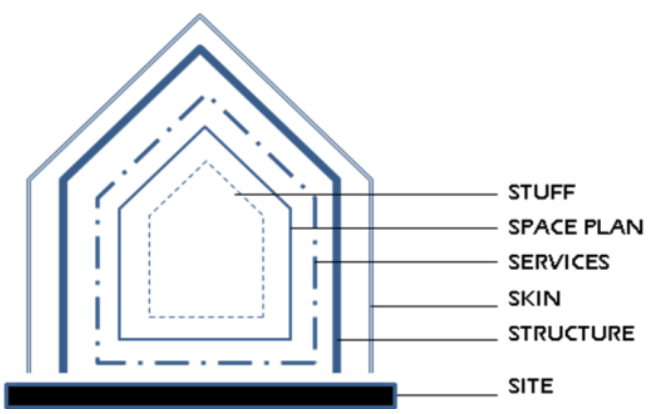

Figure 1. Division of building layer according to Brand

It can be assumed that adaptability, especially structural adaptability is highly dependent on structure and construction system. Adaptable building should apply structure systems that allow division of building into layers. In fact, the structure systems of low cost apartments in Indonesia generally and in Surabaya particularly, are mostly of concrete rigid frame, in which division into layers is impossible. That is why possible adaptability can be expected is only by relying on other than structure system. Thus, other possible determinants for adaptability instead of main structure system, is crucial to be found.

\section{RESULTS}

Despite only 16 households or 5\% respondents install mezzanine, the existence and proportion within the units needs to be learned in order to consider which proportional ceiling height will allow residents to extend vertically, but not too much as the financial capability of government in providing the apartments for low income families is very limited. For example, according to standard, the minimum ceiling height as suggested is $2 \mathrm{~m}$. Yet, although the bottom space of mezzanine mostly (50\%) has more than $2 \mathrm{~m}$ height, the top space may provide starting from $1.6 \mathrm{~m}$. For 5 storey building, this $40 \mathrm{~cm}$ difference per floor economically means a lot.

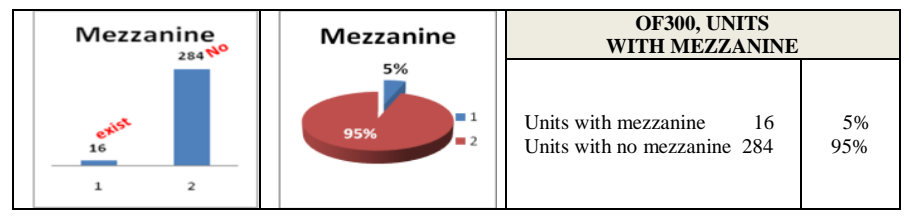

Figure 2. Conditions caused by adaptability

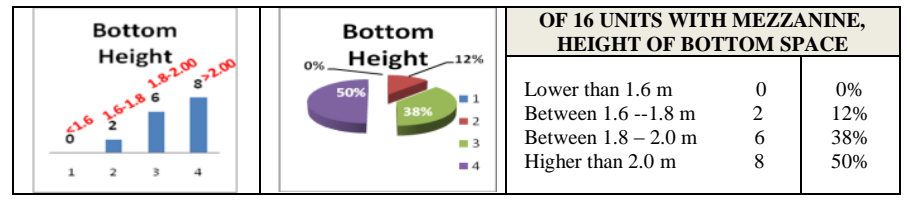

Figure 3. Height of space below mezzanine

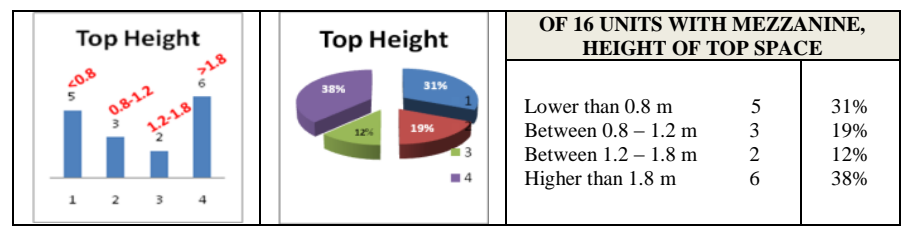

Figure 4. Height of space above mezzanine

There are 23 families or $8 \%$ of population who extend their balcony. From figure 6, it is assumed that most households who extend their balcony only need to expand shorter than $1 \mathrm{~m}$ outward, as they require this extension just for putting kitchen utensils such as pans, fryers, etc for the daily cooking which occupies only small outer distance from the original border of the balcony. This finding is expected to control the consideration in deciding the possibility of balcony extension in the recommendation.

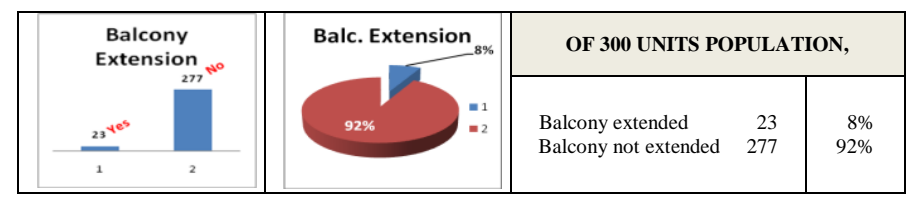

Figure 5. Households extend their balcony

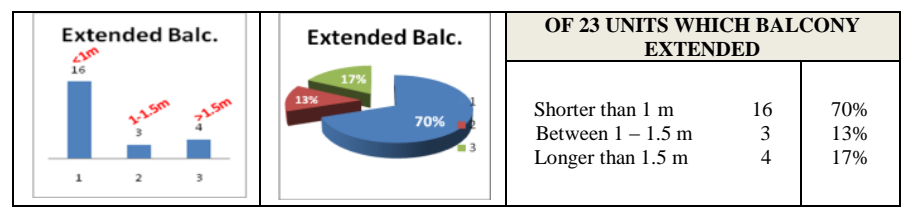

Figure 6. Distance of extended balcony 
$32 \%$ or 97 of 300 households occupy the corridor which is a public space therefore residents actually have no right to occupy this space. But, for low income apartments this attitude is regarded as normal. Additionally, figure 8 indicates that most of those who occupied the corridor i.e. $56 \%$ confiscate only narrower than $1 \mathrm{~m}$ of corridor width. Normally they use this space for putting small furniture for relaxing or entertaining such as a bench, chair, etc.

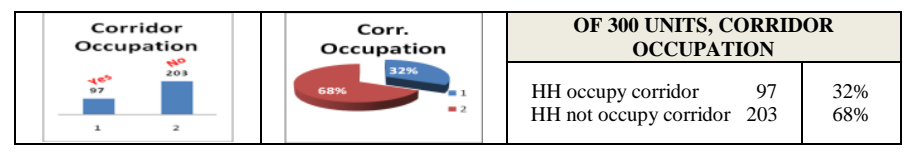

Figure 7. Households occupy corridor

\begin{tabular}{|c|c|c|c|c|}
\hline \multirow{2}{*}{ 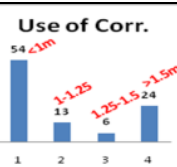 } & \multirow{2}{*}{ Use of Corr. } & \multicolumn{3}{|c|}{$\begin{array}{c}\text { OF } 97 \text { UNITS OCCUPYING } \\
\text { CORRIDOR }\end{array}$} \\
\hline & & $\begin{array}{l}\text { Narrower than } 1 \mathrm{~m} \\
\text { Between } 1-1.25 \mathrm{~m} \\
\text { Between } 1.25-1.5 \mathrm{~m} \\
\text { Wider than } 1.5 \mathrm{~m}\end{array}$ & $\begin{array}{r}54 \\
13 \\
6 \\
24\end{array}$ & $\begin{array}{c}56 \% \\
13 \% \\
6 \% \\
24 \%\end{array}$ \\
\hline
\end{tabular}

Figure 8. Distance / width of corridor used

\section{ANALYSIS}

Different from functionality which maintains the building function from the user side, adaptability of space design prolongs the building function through the building side. Both of them support sustainability. Adaptability in this research is basically the changing capability of low cost apartment space design in order to meet the users' spatial changing demands. As a result, adaptability depends on each physical structure of the building therefore its capability is determined by each structural system and dimension. Thus, in this research, the adaptability is assessed towards each building among 14, and concentrated on the possibility to change in volume vertically and horizontally. Vertically, it is assessed through possibility to extend upward by installation of mezzanine within multifunction zone. Horizontally it is assessed through two extension possibilities i.e. to the front by balcony extension and to the backward by corridor occupation.

When dealing with vertical extension, the direct aspect concerned is the third space dimension i.e. the unit height. Accordingly, the height of each low cost apartment unit determines its possibility to extend the space, which in this case the construction of mezzanine, or it can be just an addition of top part of the unit space that could be for storing or else. The crucial influence then is the height of human, as to be habitable extension space, standing inhabitants should be managed to accommodate. Therefore the height of low cost apartment unit is in this case determines the adapting capability. The normal space height after instalment below the mezzanine should be at least 2.00 meter.

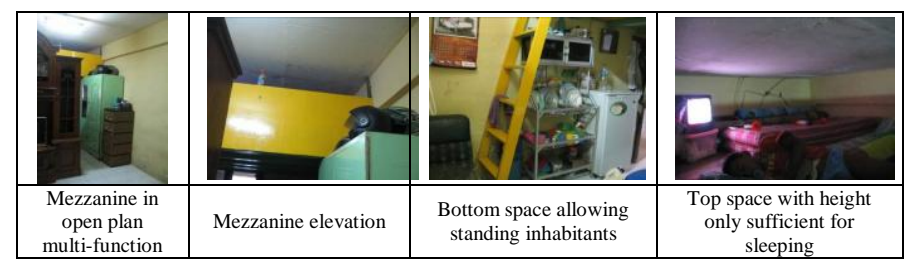

Figure 9. Illustration of mezzanine construction
When dealing with horizontal extension, then the most concerned feature is the width and the length of the space. In this research, the possibility to extend the current unit space is only towards the length, namely to the front and to the backward, as both right and left sides of unit space already belong to neighbours. That is why the possibility to extend horizontally is by occupying the corridor to the front, and by extending the balcony to the backward.

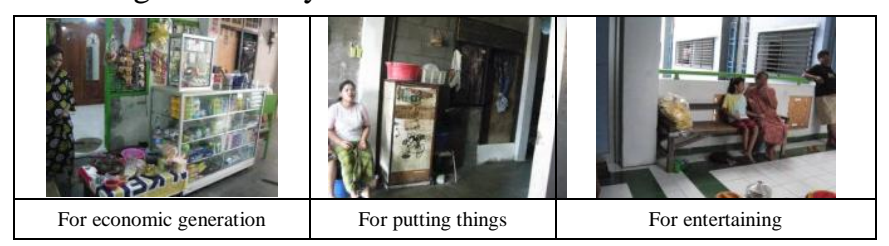

Figure 10. Illustration of corridor occupation

As discussed previously, vertical extension deeply dependable on the unit height. When original unit height, excluding the structural thickness, capable to be extended for more than 1.60 meter (the Indonesian human height data) vertically, then space design with unit height of more than 3.60 can be considered highly adaptable $(\mathrm{H})$. When the capability to extend vertically is only 1.00 meter (height of sitting human), the mezzanine space is still habitable but just allowing for sleeping. Based on this, apartments with unit ceiling height between 3.00-3.60 meters, is categorized as adaptable (A). Capability of vertical space extension lower than 1.00 meter is no longer habitable, but maybe useful for storing things. Yet convenient storing requires sufficient space height $(0.70 \mathrm{~m})$ to allow users arranging their storages. The lower the less convenient to store, therefore unit height of 2.70-3.00 meters is classified as less adaptable (L). From the discussion above it can be assumed that unit height less than 2.70 meter is considered inadaptable (I).

The occupation of corridor of course depends on the width of each low cost apartment corridor. The crucial determinant feature then is the width of human body size i.e. $0.60 \mathrm{~m}$ (de Chiara et al 1992, Neufert 1980, Fairweather and Sliwa 1972), since the corridor main function is for the horizontal circulation of users to reach their units from the stair halls. Based on this, corridor width of 1.20 meters and less has no chance to be occupied, as the space width only sufficient for 2 passengers (the minimum width of public circulation), therefore grouped as inadaptable (I). Corridor width between 1.20 and 1.50 meters considered less adaptable (L), as it gives a little chance for users to put small belongings within $30 \mathrm{~cm}$. Adaptable corridor (A) is given to width between 1.50 and 2.40 meters in which two people may pass conveniently, while the rest 0.30 up to 1.20 meter can be occupied by users more freely. Having learned these previous discussions, corridor width of more than 2.40 can be considered as highly adaptable $(\mathrm{H})$.

The adaptability is assessed towards each building sample among 14 types of low cost apartments in Surabaya. The vertical adaptability is assessed based on unit height capability dealing with mezzanine instalment possibility. The horizontal adaptability is assessed by two: capability of corridor deals with space occupation chance, and capability of cantilever structure dealing with balcony extension possibility. 


\section{A. Possibility to extend vertically by installing mezzanine}

From table I below it can be seen that by having ceiling height of 2.65, Penjaringan-3 and Asrama ITS considered inadaptable, as the possibility to be extended vertically is only less than $0.70 \mathrm{~m}$. which permits no living except for storing. Meanwhile, Sombo and Simolawang which ceiling height are $3.00 \mathrm{~m}$, Penjaringan-1, Penjaringan-2, Wonorejo, and UNESA which height are $2.80 \mathrm{~m}$, and Waru-Gunung which height is 2.75, as well as Tanah-Merah which height is $2.85 \mathrm{~m}$, judged as less adaptable as the possibility of vertical extension are between 0.70-1.00 meter that suffice only sitting human. From all the building populations, Dupak by its 3.05 height, Urip-S by 3.15 of height, and Randu and Gunungsari which have the greatest ceiling height i.e. $3.40 \mathrm{~m}$, are considered adaptable since their possibility to extend vertically is more than 1.00 which provides more habitable space for human. No low cost apartment in this research is considered highly adaptable with ceiling height higher than 3.60 which may provide top space for standing human freely.

TABLE I. VERTICAL ADAPTABILITY OF LOW COST APARTMENTS

\begin{tabular}{|c|c|c|c|c|c|c|c|c|c|}
\hline \multirow{2}{*}{\multicolumn{2}{|c|}{$\begin{array}{c}\text { LOW COST } \\
\text { APARTMENT (LCA) }\end{array}$}} & \multicolumn{4}{|c|}{ UNIT HEIGHT } & \multicolumn{4}{|c|}{ ADAPTABILITY } \\
\hline & & \multirow{2}{*}{$\begin{array}{l}>3.60 \\
\mathrm{M}\end{array}$} & \multirow{2}{*}{$\begin{array}{r}3.00- \\
3.60 \mathrm{M}\end{array}$} & \multirow{2}{*}{$\begin{array}{c}\begin{array}{c}2.70- \\
3.00 \mathrm{M}\end{array} \\
3.00\end{array}$} & \multirow{2}{*}{$\begin{array}{l}<2.70 \\
M\end{array}$} & \multirow{2}{*}{ H } & \multirow{2}{*}{ A } & \multirow{2}{*}{$\begin{array}{l}\mathbf{L} \\
\mathrm{V}\end{array}$} & \multirow{2}{*}{ I } \\
\hline 1 & Sombo & & & & & & & & \\
\hline 2 & Simolawang & & & 3.00 & & & & $\mathrm{~V}$ & \\
\hline 3 & Dupak & & 3.05 & & & & $\mathrm{~V}$ & & \\
\hline 4 & Penajringan-1 & & & 2.80 & & & & $\mathrm{~V}$ & \\
\hline 5 & Penjaringan-2 & & & 2.80 & & & & $\mathrm{~V}$ & \\
\hline 6 & Wonorejo & & & 2.80 & & & & $\mathrm{~V}$ & \\
\hline 7 & Randu & & 3.40 & & & & $\mathrm{~V}$ & & \\
\hline 8 & Gunungsari & & 3.40 & & & & $\mathrm{~V}$ & & \\
\hline 9 & Waru Gunung & & & 2.75 & & & & $\mathrm{~V}$ & \\
\hline 10 & $\begin{array}{l}\text { Urip } \\
\text { Sumoharjo }\end{array}$ & & 3.15 & & & & $\mathrm{~V}$ & & \\
\hline 11 & Tanah Merah & & & 2.85 & & & & $\overline{\mathrm{V}}$ & \\
\hline 12 & Penjaringan-3 & & & & 2.65 & & & & $\mathrm{~V}$ \\
\hline 13 & Asrama ITS & & & & 2.65 & & & & $\overline{\mathrm{V}}$ \\
\hline 14 & UNESA & & & 2.80 & & & & $\mathrm{~V}$ & \\
\hline
\end{tabular}

\section{B. Possibility to occupy corridor}

In this research, no low cost apartment is considered inadaptable, as the corridor width is all more than $1.20 \mathrm{~m}$. By having corridor width of $1.50 \mathrm{~m}$, Waru Gunung, Tanah-Merah, Penjaringan-3, Asrama ITS, and UNESA, are judged less adaptable, since the possibility of corridor occupation is just $0.30 \mathrm{~m}$ of the width, as $1.20 \mathrm{~m}$ of the corridor width should be left free for two way public circulation. This means that the corridor occupation is only possible such as for putting small shoe rack, dust bin, or planting. Randu and Tanah-Merah have wider corridor i.e. 2.00 therefore they are judged adaptable as by releasing $1.20 \mathrm{~m}$ for circulation they still have $0.80 \mathrm{~m}$ of corridor width to be occupied, in which they can entertain, play, or child-care, in a more relieving spare space. From all 14 building population, 7 of them i.e. Sombo, Simolawang, Dupak, Penjaringan-1, Penjaringan-2, Wonorejo and Gunungsari, can be judged highly adaptable as they have 3.00 corridor width, thus occupation up to $1.80 \mathrm{~m}$ for 2 adjacency units is therefore $0.90 \mathrm{~m}$ each still possible.
TABLE II. CORRIDOR OCCUPATION POSSIBILITY

\begin{tabular}{|c|l|c|c|c|c|c|c|c|c|}
\hline \multirow{2}{*}{$\begin{array}{c}\text { LOW COST } \\
\text { APARTMENT (LCA) }\end{array}$} & $\begin{array}{c}\mathbf{7 2 . 4 0} \\
\mathbf{M}\end{array}$ & $\begin{array}{c}\mathbf{1 . 5 0} \\
\mathbf{2 . 4 0} \mathbf{M}\end{array}$ & $\begin{array}{c}\mathbf{1 . 2 0} \\
\mathbf{1 . 5 0} \mathbf{~ M}\end{array}$ & $\begin{array}{c}<\mathbf{1 . 2} \\
\mathbf{0 ~ M}\end{array}$ & H & A & L & I \\
\hline $\mathbf{1}$ & Sombo & 3.00 & & & & $\mathrm{~V}$ & & & \\
\hline $\mathbf{2}$ & Simolawang & 3.00 & & & & $\mathrm{~V}$ & & & \\
\hline $\mathbf{3}$ & Dupak & 3.00 & & & & $\mathrm{~V}$ & & & \\
\hline $\mathbf{4}$ & Penajringan-1 & 3.00 & & & & $\mathrm{~V}$ & & & \\
\hline $\mathbf{5}$ & Penjaringan-2 & 3.00 & & & & $\mathrm{~V}$ & & & \\
\hline $\mathbf{6}$ & Wonorejo & 3.00 & & & & $\mathrm{~V}$ & & & \\
\hline $\mathbf{7}$ & Randu & & 2.00 & & & & $\mathrm{~V}$ & & \\
\hline $\mathbf{8}$ & Gunungsari & 3.00 & & & & $\mathrm{~V}$ & & & \\
\hline $\mathbf{9}$ & Waru Gunung & & & 1.50 & & & & $\mathrm{~V}$ & \\
\hline $\mathbf{1 0}$ & Urip Sumoharjo & & 2.00 & & & & $\mathrm{~V}$ & & \\
\hline $\mathbf{1 1}$ & Tanah Merah & & & 1.50 & & & & $\mathrm{~V}$ & \\
\hline $\mathbf{1 2}$ & Penjaringan-3 & & & 1.50 & & & & $\mathrm{~V}$ & \\
\hline $\mathbf{1 3}$ & Asrama ITS & & & 1.50 & & & & $\mathrm{~V}$ & \\
\hline $\mathbf{1 4}$ & UNESA & & & 1.50 & & & & $\mathrm{~V}$ & \\
\hline
\end{tabular}

\section{Possibility to extend the balcony}

From all 14 low cost apartments in this research, 9 of them are inadaptable in terms of balcony extension. The reason is because 5 of them have no balcony, and balconies of 4 of them i.e. Sombo, Simolawang, Dupak, and Penjaringan-1, are structured continuously, so they are incapable to be extended privately. Only 5 apartments have the capability for corridor extension, yet only 4 of them i.e. Penjaringan-2, Wonorejo, Randu, and Penjaringan-3, judged as adaptable since their corridor are privately structured, with distance below the maximum, thus the cantilever beam still permit extension. Less-capability of balcony extension is overcome by Urip-S because of its structure system and shape.

\section{TABLE III. BALCONY EXTENSION POSSIBILITY}

\begin{tabular}{|c|c|c|c|c|c|c|c|c|c|}
\hline \multirow{2}{*}{\multicolumn{2}{|c|}{$\begin{array}{c}\text { LOW COST } \\
\text { APARTMENT (LCA) }\end{array}$}} & \multicolumn{4}{|c|}{ BUILDING STRUCTURE } & \multicolumn{4}{|c|}{ ADAPTABILITY } \\
\hline & & System & Distance & System & Distance & $\mathbf{H}$ & $\mathbf{A}$ & $\mathbf{L}$ & I \\
\hline 1 & Sombo & Continuously & 1.50 & Impossible & & & & & $\mathrm{V}$ \\
\hline 2 & Simolawang & $\begin{array}{l}\text { Continuously } \\
\end{array}$ & 1.50 & Impossible & & & & & $\overline{\mathrm{V}}$ \\
\hline 3 & Dupak & Continuously & 1.50 & Impossible & & & & & $\overline{\mathrm{V}}$ \\
\hline 4 & Penajringan-1 & Continuously & 1.50 & Possible & & & & & $\mathrm{V}$ \\
\hline 5 & Penjaringan-2 & $\begin{array}{l}\text { Privately } \\
\end{array}$ & 2.00 & Possible & & & $\mathrm{V}$ & & \\
\hline 6 & Wonorejo & Privately & 2.00 & Possible & & & $\mathrm{V}$ & & \\
\hline 7 & Randu & Privately & 1.00 & Possible & & & $\mathrm{V}$ & & \\
\hline 8 & Gunungsari & Nil & & & & & & & $\overline{\mathrm{V}}$ \\
\hline 9 & Waru Gunung & $\overline{\mathrm{Nil}}$ & & & & & & & $\mathrm{V}$ \\
\hline 10 & $\begin{array}{l}\text { Urip } \\
\text { Sumoharjo }\end{array}$ & Privately & 0.80 & Possible & & & & $\mathrm{V}$ & \\
\hline 11 & Tanah Merah & Nil & & & & & & & $\mathrm{V}$ \\
\hline 12 & Penjaringan-3 & Privately & 1.20 & Possible & & & $\mathrm{V}$ & & \\
\hline 13 & Asrama ITS & Nil & & & & & & & $\overline{\mathrm{V}}$ \\
\hline 14 & UNESA & $\mathrm{Nil}$ & & & & & & & $\mathrm{V}$ \\
\hline
\end{tabular}

\section{CONCLUSION}

Conclusion of adaptability of current space design is structured respectively based on all the research objects. Therefore this section is started from the adaptability of Sombo, Simo, Dupak, Penjar-1, Penjar-2, Wonorejo, Randu, Gunungsari, Waru-Gunung, Urip-S, Tanah-Merah, Penjar-3, ITS, and concluded by the adaptability of UNESA.

Sombo and Simo have similar space design. By having ceiling height of $3 \mathrm{~m}$, vertical adaptability of Sombo and Simo are assessed less adaptable, as the upper part height of mezzanine will only manage to reach $1 \mathrm{~m}$ after reduced by $2 \mathrm{~m}$ for the bottom space, by which human cannot stand freely, but this height still allows sitting and sleeping activities. For 
horizontal adaptability frontward, by having $3 \mathrm{~m}$ corridor width, Sombo and Simo can be assessed highly adaptable since after reduced by $1.2 \mathrm{~m}$ for circulation, occupation towards corridor up to $1.8 \mathrm{~m}$ for both side units, or $0.9 \mathrm{~m}$ each is still possible. For backward adaptability, by having continuous structure, balcony extension on Sombo and Simo is impossible, therefore they are assessed inadaptable.

Dupak has $5 \mathrm{~cm}$ higher than Sombo and Simo, that's why its vertical adaptability is assessed adaptable, as it has upper space height $1.05 \mathrm{~m}$, where human feels a bit relieved in it. The rests, Dupak is designed exactly similar to Sombo and Simo,. Accordingly, its corridor occupation possibility also assessed highly adaptable, and its balcony extension capability is assessed inadaptable as well.

By having $2.8 \mathrm{~m}$ ceiling height, possibility for mezzanine construction of Penjar-1 units is lesser, therefore assessed less adaptable, as the possible height of upper space is minimal i.e. $0.8 \mathrm{~m}$ where human in it only capable to sleep, otherwise the mezzanine functions only for storing things. As the corridor width is $3 \mathrm{~m}$, possibility of corridor occupation of Penjar-1 assessed highly adaptable. The continuous balcony made the extension of balcony on Penjar-1 impossible, therefore assessed inadaptable.

Penjar-2 and Wonorejo have exactly the same space design. By having ceiling height of $2.8 \mathrm{~m}$, vertical adaptability of them are assessed less adaptable, as the upper part height of mezzanine will only manage to reach $0.8 \mathrm{~m}$ after reduced by $2 \mathrm{~m}$ for the bottom space, by which human cannot stand, but still able to sit and sleep on it. For horizontal adaptability frontward, by having $3 \mathrm{~m}$ corridor width, Penjar-2 and Wonorejo are assessed highly adaptable since after reduced by $1.2 \mathrm{~m}$ for circulation, occupation towards corridor up to $1.8 \mathrm{~m}$ for both side units, or $0.9 \mathrm{~m}$ each is still possible. For backward adaptability, by having privately structured balcony with $2 \mathrm{~m}$ distance, extension of balcony is possible, and assessed adaptable. Yet as maximum cantilever arm permitted is normally $2.75 \mathrm{~m}$, possible extension is only $0.75 \mathrm{~m}$ outward.

Randu has the highest ceiling height among all research objects i.e. $3.4 \mathrm{~m}$. By this height the possibility of mezzanine construction assessed adaptable, and the height of upper space achieves $1.4 \mathrm{~m}$ where adult people in it feels more convenient, and standing children still possible. Having $2 \mathrm{~m}$ corridor width and privately structured balcony enables Randu assessed adaptable both for possibility of corridor occupation and balcony extension.

Similar to Randu, Gunungsari has the highest ceiling i.e. $3.4 \mathrm{~m}$ that is why the possibility of mezzanine construction assessed highly adaptable. The $3 \mathrm{~m}$ corridor also considered the widest among others therefore its possibility of corridor occupation assessed highly adaptable. Yet, Gunungsari has no balcony, thus its impossibility to extend made the balcony extension of Gunungsari assessed inadaptable.
By having only $2.75 \mathrm{~m}$ ceiling height, possibility of mezzanine construction of Waru Gunung assessed less adaptable. Top space height of $0.75 \mathrm{~m}$ only allows installment of low storing space. Corridor width of $1.5 \mathrm{~m}$ made the possibility of corridor occupation of Waru Gunung assessed less adaptable. Inexistence of balcony results in impossibility of balcony extension therefore assessed inadaptable.

Urip-Sumoharjo has higher than $3 \mathrm{~m}$ ceiling height i.e. $3.15 \mathrm{~m}$, by which its possibility of mezzanine construction assessed adaptable, with possible upper space height of $1.15 \mathrm{~m}$. This means quite relieving space for living although only for sitting and sleeping is possible. By having $2 \mathrm{~m}$ corridor width, the possibility of corridor occupation assessed adaptable. Privately structured cantilever on each balcony but in distinct shape of cantilever arm with short distance i.e. $0.8 \mathrm{~m}$, made possibility of balcony extension of Urip-S assessed less adaptable.

Having $2.85 \mathrm{~m}$ ceiling height and only $1.5 \mathrm{~m}$ corridor width, possibility of both mezzanine construction and corridor occupation of Tanah Merah are assessed less adaptable. Inexistence of balcony made this balcony impossible to extend therefore assessed inadaptable.

Penjar-3 and ITS have the lowest ceiling height among others i.e. $2.65 \mathrm{~m}$ therefore possibility of mezzanine construction assessed inadaptable. $1.5 \mathrm{~m}$ corridor width made the possibility of corridor occupation of Penjar-3 assessed less adaptable. Yet, $1.2 \mathrm{~m}$ balcony distance that structured privately enables possibility of balcony extension of Penjar-3 assessed adaptable.

Similar to Penjar-3, ceiling height of $2.65 \mathrm{~m}$ made possibility of mezzanine of ITS assessed inadaptable. The $1.5 \mathrm{~m}$ corridor width results in possibility of corridor occupation of ITS assessed less adaptable. As having only small balcony that considered almost not exist, inadaptable assessment is obtained by ITS on possibility of balcony extension.

By having $2.8 \mathrm{~m}$ ceiling height and $1.5 \mathrm{~m}$ corridor width, both possibility of mezzanine construction and corridor occupation of UNESA are assessed less adaptable. The inexistence of balcony causing possibility of balcony extension of UNESA assessed inadaptable. 


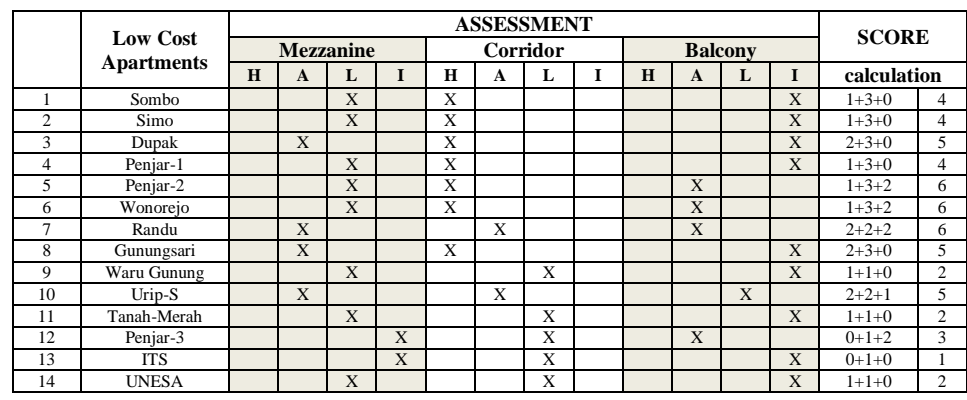

Having learned the above recapitulation table, by giving score of 3 for highly adaptable, 2 for adaptable, 1 for less adaptable, and 0 for inadaptable, it can be seen that achieving total score of 6, Penjaringan-2, Wonorejo and Randu successfully nominated as the most adaptable low cost apartments in Surabaya, followed by Dupak, Gunungsari, and Urip-Sumoharjo as the second best by having total score of 5 , and by collecting score of 4, Sombo, Simo and Penjar-1 placed in the third in terms of physical adaptability, followed by Penjaringan-3 in the fourth that scored 3. The most inadaptable low cost rental apartment is ITS after the place of Waru Gunung, Tanah Merah, and UNESA which only manage scored 2.

\section{REFERENCES}

[1] Brand Steward. "How Buildings Learn What Happens After They're Built”. Penguin Group, Penguin Books USA Inc. Hudson New York, New York 10014 USA. 1994.
[2] Chiara Joseph De, Panero and Zelnik. "Time Saver Standard for Interior Design and Space Planning (book)". Published by Mc.Graw Hill, New York. 1992.

[3] Duffy F, and Hannay P (editor). "The Changing Work Place".Phaidon Press Ltd. 24 April 1992.

[4] Fairweather and Sliwa. "AJ Metric Handbook (book)". The architectural Press, London. 1972.

[5] Geraedts Rob. "Future Value of Buildings". Faculty of Architecture University of Technology, Delft, the Netherlands. 2001.

[6] Habraken N.J. (1966) 'Three R's for housing' Forum, 20(1); bilingual reprint, Scheltema \& Holkema, Amsterdam. 1966.

[7] Jia Beisi. “Adaptable Housing or Adaptable People?". Experience in Switzerland gives a new answer to the questions of housing adaptability. Department of Architecture Swiss Federal Institute of Technology $\mathrm{CH}$ 8093 Zurich Switzerland. Arch \& Comport 1 Arch \& Behav Vol.11, no2, 1993. p139-162.

[8] Manning P. "Environmental Evaluation". Building Environment 1987 vol.22. Issue 3, 1987. p.201-208. [cited 27.07.2012] http://www.sciencedirect.com/science/article/pii/0360132387900084

[9] Moffatt and Russel, 2001. "Assessing the Adaptability of Buildings". Energy-Related Environmental Impact of Buildings. 2001.

[10] Neufert Ernst. "Neufert Architect Data (book)". Granada Publishing Limited. James street, London. UK. 1980

[11] Voordt T. JM van der, Vrielink D, Wegen H. BR van. "Comparative Floorplan Analysis in Programming and Design". Design Studies, 1997, No. 18, p. 67-88 [cited 27.07.2012]. http://www.retudelft.nl/fileadmin/Faculteit/BK/Over de faculteit/Afdelingen/Real Es tate_and_Housing/Organisatie/Medewerkers_RE_H/Personal_pages/Va nderVoordt/General_list/doc/1997-

designStudies_Comparativefloorplananalysis_Voordtetal.pdf 